\title{
Refleksje o edukacji w dobie przemian globalizacyjnych
}

\section{KEY WORDS}

education, job market, globalization

\begin{abstract}
Myszka Lucyna, Refleksje o edukacji w dobie przemian globalizacyjnych [Education in the World of Globalization]. Kultura - Społeczeństwo - Edukacja nr 1(7), 2015, Poznań 2015, pp. 75-89, Adam Mickiewicz University Press. ISBN 978-83-232-2944-5. ISSN 2300-0422
\end{abstract}

As a consequence of globalization human life is subjected to many mechanisms that go along with it for example homogenization, culture diffusion, consumptionism, relativism and constant change, which lead to unreflectiveness affecting all aspects of human life. A human beeing exists in a common reality in accordance to a very flexible scenario, without much thought about the sense of existence. This situation reflects on education, which should concentrate on efficent spreading of knowledge and skills necessary to live in current conditions, which are a source of many chances but also dangers. Those changes can't be analyzed without taking markets into consideration, understood as having and usefulness. Those trends cause the "production" of alumni that are very efficient from an economical point of view and oriented on self realization, but aren't oriented on reflective exploration of the world. This situation results in comparing humans to machines and in an obsessive want of getting a diploma which certifies obtaining education understood as a commodity. This in turn is an incentive to reflect upon the foundations of education a process that is the most important investment in the development of human capital.

Edukacja staje się jedną z najważniejszych aktywności życiowych współczesnego człowieka. Konieczność implementacji zasady longlife learning stanowi atrybut egzystencji podmiotu w czasach „migotania znaczeń” (Melosik, Szkudlarek, 2010) oraz „płynnego życia” (Bauman, 2007). Powyższe stwierdzenie wydaje się trywialne, jednak jego głębsza analiza pozwala dostrzec nowy wymiar edukacji. Dotychczas identyfikowano ją z procesem prowadzącym do zdobycia wykształ- 
cenia, pełniącego rolę głównego czynnika determinującego przyszłość zawodową jednostki. Jej trajektoria przybierała postać linii wznoszącej, która w pewnym momencie osiągała stabilizację. Obecnie coraz częściej ludzkie biografie charakteryzuje przebieg sinusoidalny, przeplatanie się okresów sukcesów oraz porażek na płaszczyźnie edukacyjno-zawodowej aktywności podmiotu (Gerlach, 2006: 177).

Redefinicja edukacji, dająca się zaobserwować akceleracja życia oraz rzeczywistość nowej jakości stanowią wynik procesów globalizacyjnych ${ }^{1}$. Konglomerat warunkowanych przez nie zmian odkrywa "nowy nieporządek świata” (Bauman, 2000a: 71) oraz „wzajemnie przenikające się subprzestrzenie” (Burszta, 1998: 159), mające wymiar zarówno ekonomiczno-gospodarczy, jak i społeczny. Mimo że pojęcie "globalizacja” na polu badawczym funkcjonuje od niedawna i nie ma utrwalonej tradycji ${ }^{2}$, pozostaje $\mathrm{w}$ zasięgu zainteresowania wielu dyscyplin naukowych, takich jak filozofia, pedagogika, socjologia, politologia i ekonomia. Zapoczątkowało ono dyskurs koncentrujący się na analizie życia współczesnego człowieka, uwikłanego w oddziaływanie mechanizmów homogenicznego świata.

Badacze zjawiska dopatrują się różnych źródeł globalizacji. Stosunkowo często można spotkać się ze stwierdzeniem, że stanowi ona następstwo tak zwanej trzeciej rewolucji przemysłowej, określanej mianem informatycznej, której specyfika odnosi się do szybkiego postępu technologicznego, oddziałującego na wszelkie sfery ludzkiej egzystencji (Mayor, 2001: 12-13). W innych ujęciach zwraca się uwagę na wszechobecność konsumpcji, upowszechnienia się macdonaldyzacji (zob. Ritzer, 1997), dążącej do wprowadzenia zasad obowiązujących w restauracjach z szybkim jedzeniem we wszystkich dziedzinach życia, oraz unifikację kulturową, skutkującą kształtowaniem się kultury o zintegrowanym charakterze ponadnarodowym (Mathews, 2005). Warto zaznaczyć, że specyfika globalizacji nie wynika wyłącznie ze współczesnych przemian ogólnoświatowych, ale stanowi konsekwencję wcześniejszych procesów historycznych, których zrozumienie pozwala na trafniejsze dookreślenie rozpatrywanej kategorii (Cybal-Michalska, 2006: 23-30). Uzasadniona pozostaje zatem konkluzja traktująca o permanentnym rozwoju tendencji globalizacyjnych, będących konsekwencją postępujących zmian cywilizacyjnych.

W refleksji nad złożonym, wielowymiarowym i trudnym do zdefiniowania konstruktem, jaki stanowi globalizacja, kluczową rolę odgrywa przeanalizowanie sposobów jej ujmowania. Zrozumienie tego fenomenu pozwala na udzielenie odpowiedzi na pytanie: „co dzieje się na świecie?”. Dlatego też uzasadniona wy-

${ }^{1}$ Dokonujące się przemiany postrzegane są jednocześnie jako tło (kontekst) myślenia o współczesnej edukacji, bez analizy którego nie sposób rozważać tego zagadnienia.

${ }^{2}$ Po raz pierwszy zostało użyte przez R. Robertsona w pracy The Relativization of Societies: Modern Religion and Globalization w 1985 roku. 
daje się konkluzja traktująca o tym, że jest ona nieuniknionym i nieodwracalnym procesem sterującym niemal wszystkimi aspektami funkcjonowania współczesnej rzeczywistości. Wyróżnia się dwa paradygmaty globalizacji - jeden z nich odnosi się do zagadnień gospodarczo-ekonomicznych, drugi do płaszczyzny społeczno-kulturalnej (zob. Giddens, 1997). Pomimo znaczącego dorobku naukowego, koncentrującego się na uporządkowaniu wiedzy dotyczącej przemian cywilizacyjnych i rozwoju społeczeństw, nie stworzono całościowej teorii globalizacji (Hornstein, 2005: 9). Fakt ten dowodzi niejednoznaczności rozpatrywanego terminu, którego znaczenia pozostają w ścisłej relacji $\mathrm{z}$ ambiwalencją i niepewnością obecnego świata.

Omawiane zjawisko w literaturze przedmiotu najczęściej określane jest jako proces tworzenia jednolitej płaszczyzny gospodarczej (wspólnego rynku) na arenie międzynarodowej, skutkujący osłabieniem barier lokalnych, regionalnych i krajowych oraz kontynentalnych ${ }^{3}$. Prawidłowość taka świadczy o determinującym znaczeniu globalizacji w przeobrażeniach porządku międzynarodowego. Powstawanie sieci współzależności różnorodnych dziedzin życia społecznego implikuje kształtowanie relacji, których oddziaływanie nie pozostaje bez znaczenia dla kreowania nowej jakości porządku kulturowego zarówno w skali mikro, jak i makro. Pozostają jednak obszary geograficzne, w których oddziaływanie procesów globalizacyjnych ma ograniczone znaczenie, co skutkuje ich marginalizacją i pogłębianiem się nierówności (Bauman, 2000a: 81). Najczęściej wskazuje się tutaj na kraje Trzeciego Świata (Golka, 1999), w których zjawisko ubóstwa oraz trudności w zapewnieniu warunków egzystencjalnych o odpowiednim standardzie są powszechne.

Dyskurs obejmujący rozpatrywane zagadnienie ujawnia dychotomiczną naturę tego konstruktu. Nadaje się mu charakter zarazem homogeniczny ${ }^{4}$ i heterogeniczny $^{5}$, globalny i lokalny, różnorodny i uniwersalny, dostrzega się w nim także źródła rywalizacji międzynarodowej oraz powstawania ponadnarodowych

${ }^{3}$ Szul, 1997: 341. Podobne znaczenie tego wymiaru globalizacji, często określanego mianem ekonomicznej, nadaje także B. Liberska, definiując ją jako „postępujący proces integrowania się krajowych i regionalnych rynków w jeden globalny rynek towarów, usług i kapitału. Proces ten prowadzi do rosnącego przenikania i scalania się rynków oraz umiędzynarodowienia produkcji, dystrybucji, marketingu i przyjęcia przez firmy globalnych strategii działania (Liberska, 2002: 17-18).

${ }^{4}$ Zwolennikami tego podejścia są między innymi M. Golka, H.P. Martin, H. Schumann, M. Albrow, R. Robertson. Rozpatrują je w kategoriach procesów, które prowadzą do ujednolicania struktury świata. Koncentrują się na zjawisku dyfuzji kultur, w której dominującą rolę pełniła kultura społeczeństw zachodnich.

${ }^{5}$ Wydźwięk tej opinii można odnaleźć w rozstrzygnięciach, które proponują Ch. Barker, A. Giddnes, A. McGrew, P. Streenten, L. Roniger. Ujmują oni globalizację w kategoriach różnorodności, które wyznaczają kierunek rozwoju współczesnych społeczeństw. 
sieci współpracy. Globalizacja określa zatem „zarówno rozpowszechnianie, unifikację pewnych zachowań, jak również przenikanie się - dzięki szybkiemu rozwojowi technologii - różnych kultur” (Kukla, 2010: 18). Dlatego też zasadne wydaje się ujmowanie globalizacji jako

procesu integracji $\mathrm{w}$ wymiarze gospodarczym, $\mathrm{z}$ wyraźnym przeciwstawieniem globalizacji procesom ulokalnienia, albo jako dynamika kultury globalnej determinującej proces unifikacji ekonomicznej i politycznej świata. Globalizacja odnosi się więc z jednej strony do kurczenia się świata, a z drugiej strony - do narastania świadomości owej całości i różnorodności świata zarazem. (Cybal-Michalska, 2006: 11)

W kontekście powyższych rozważań nie można pominąć kwestii przemian społeczno-kulturowych, które stanowią konsekwencję wspomnianych oddziaływań globalizacyjnych. Wyraźnie dają się one zaobserwować w zmianach stylów życia współczesnych ludzi oraz tworzenia się tożsamości o heterogenicznym charakterze (Golka, 20001: 79). Zbigniew Bokszański podkreśla, że z powodu szerzenia się idei autonomii jednostki się indywidualizują, w wyniku czego zatracają orientację na zinstytucjonalizowane i powszechnie uznawane wartości i normy, co przyczynia się do osłabienia znaczenia autorytetów i sankcji społecznych. Ludzie zaczynają kreować własne biografie i osobowości, niezależne od procesów zachodzących w zbiorowości. Prowadzi to do wyzbycia się zobowiązań wobec społeczeństwa, wynikających z nieprzestrzegania zasad wspólnego życia i zorientowania się człowieka na korzyści płynące $\mathrm{z}$ alternatywnych zachowań (Bokszański, 2009: 151-169). Jednak mamy także do czynienia ze zjawiskiem tworzenia się wielu wspólnot o charakterze ponadnarodowym, mających zwrócić uwagę na fakt, że losy ludzkości stanowią temat poddawany wspólnej dyskusji (Bauman, 2000b: 352).

$\mathrm{Z}$ jednej strony mamy do czynienia $\mathrm{z}$ coraz bardziej nasilającym się zjawiskiem autonomizacji jednostek, przy jednoczesnym utożsamianiu się ich z kulturą regionalną, czego konsekwencją staje się nieprzyjazne nastawienie do osób „obcych”, przychodzących z zewnątrz (Giddens, 2008: 58), z drugiej zaś strony można zaobserwować zjawisko skłaniania się w stronę kolektywizmu, solidaryzowania się i tworzenia wspólnot, a także „uniwersalizacji” (Tobera, 2000: 14). Należy jednak zwrócić uwagę na fakt, że poruszane problemy dotyczą tylko określonych aspektów życia społecznego. Dlatego też orientowanie się w ich obrębie umożliwia jednostce zarówno bycie indywidualistą posiadającym swoje własne cele i system wartości, jak i człowiekiem działającym na rzecz dobra powszechnego, przejawiającym cechy charakterystyczne dla ogółu społeczeństwa (Dorna, 2001: 165-167). 
Jerzy Mikułowski-Pomorski zwraca uwagę na jeszcze jeden bardzo istotny element współczesnego życia, będący efektem przemian globalnych, jaki stanowi fragmentaryzacja. Interpretuje ją jako „nie zanik części dawnych całości, ich całkowity rozpad, ale trwanie ich części we fragmencie, pewnym stanie wyróżnialnym i rozpoznawalnym, zdolnym zapewne, przez pewien czas samodzielnie funkcjonować" (Mikułowski-Pomorski, 2006: 13). Podtrzymuje, że przenika wszystkie sfery życia społecznego, dlatego też można dopatrywać się w niej pewnego niebezpieczeństwa globalizacji, ponieważ zagraża wytworzonym przez nią zjednoczonym strukturom (Mikułowski-Pomorski, 2006: 15). W życiu społecznym polega ona na rozdrobnieniu kontaktów międzyludzkich oraz ich specjalizacji. Podkreśla też, że fragmentaryzacji ulega również kontekst tych relacji, który staje się charakterystyczny tylko dla poszczególnych spraw (Mikułowski-Pomorski, 2006: 26). Takie ujęcie powyższej kategorii pozostaje w bliskiej relacji z tym, co Z. Bauman określa epizodycznością, w myśl której każdy fragment życia społecznego stanowi odrębną całość (Bauman, 1993: 13).

Współczesne rozważania nad postępującymi procesami globalizacyjnymi nie są oderwane od szerokiego spektrum problemów związanych $\mathrm{z}$ edukacją. $\mathrm{W}$ sytuacji narastającego tempa życia, permanentnych przemian $i$ ambiwalencji jednostki coraz częściej zaczynają odgrywać swoje role rutynowo, bez większego namysłu. Dokonujące się przeobrażenia mające miejsce w obecnej rzeczywistości „powodują, że pojawia się silna potrzeba wypracowania wizji człowieka oraz kształtowania takiego systemu edukacji, który dałby szansę egzystencji młodym pokoleniom w świecie wielkich szans, ale także wielu zagrożeń" (Ćwikliński, 2005: 27). Skutkiem takich konotacji są coraz częstsze pytania o naturę ludzką, „obraz człowieka”, sens egzystencji, a co z tym idzie - kształt edukacji.

Zmiany zachodzące w Europie w ostatniej dekadzie XX wieku oraz na początku XXI mają doniosłe znaczenie nie tylko dla Polski i naszych sąsiadów, ale także dla całego świata, który odczuwa skutki tych przemian. Upowszechniająca się idea demokracji oraz skok cywilizacyjny wymagały opanowania nowych mechanizmów adaptacyjnych umożliwiających funkcjonowanie w zaistniałych warunkach. Przeobrażenia te przyczyniły się do wykształcenia potrzeb zorientowanych na natychmiastowe zaspokajanie pragnień i żądzy posiadania. Wielorakość oraz niebywała liczba oferowanych stylów życia i światopoglądów, a także wizji człowieczeństwa skutkuje załamaniem stabilnej struktury tożsamości. Konstruowanie osobowości oparte na tradycyjnych wartościach staje się przeżytkiem. Dlatego też wizja siebie budowana jest na zasadach wolności i kreacji, a także na podstawie własnych doświadczeń i nie wzoruje się na rutynowych rolach społecznych (Bokszański, 1988: 12). Podmiot ma wrażenie swojej wyjątkowości, jednak faktycznie zatraca swoją indywidualność i coraz bardziej upodabnia się 
do innych, podąża za modą i staje się anonimowy (Szmyd, 2006: 205-206). Zjawisko to skutkuje zatracaniem jednostkowej niepowtarzalności, zubożeniem i prymitywizacją tożsamości (Szmyd, 2006: 207). Postępujący proces kształtuje bardzo sfragmentaryzowany i niekoherentny obraz siebie, w związku z czym zaczyna przypominać hybrydę, kalejdoskop lub kolaż różnych wartości (Pucek, 2004: 34, 36-37).

Konglomerat postępujących zmian implikuje powstawanie koncepcji sprowadzających człowieka do roli maszyny autorstwa Michela Foucaulta (zob. Foucault, 1993). W kontekście powyższych rozważań jest ona interesująca poznawczo, o ile pozwala zrozumieć specyfikę społecznego funkcjonowania podmiotu, uwikłanego w konotacje mechanizmów konsumpcyjnych i cywilizacyjnych. Jednostki poddawane procesowi socjalizacji zostają zaprojektowane w myśl wcześniej przyjętego standardu. Odczuwają pozorne wrażenie wolności, jednak tak naprawdę ich decyzje są konsekwencją zaprogramowania. Podmiot, chcąc usprawnić swoje działanie (zminimalizować przeciążenie mózgu), korzysta $\mathrm{z}$ dostępnych zewnętrznych struktur (komputer, instytucje społeczne, polityczne), które wspierają go w procesie rozwiązywania problemów, w wyniku czego osłabia znaczenie indywidualnej racjonalności oraz odrębności. Ta dwukierunkowa interakcja, koncentrująca się na poszerzaniu zasobu obrazów, skutkuje poszerzaniem granicy własnego Ja (Polak, Polak, 2014: 133-139).

Tomasz Polak i Beata Anna Polak, dokonując interpretacji teorii Yara Rondona Guasque Araujo ${ }^{6}$, dowodzą doniosłości tej narracji poprzez analizę powiązanych $\mathrm{z}$ nią pojęć emergencji (łac. e-mergere - wynurzać) i immersji (łac. inmergere - zanurzać). Ze względu na ich zależności etymologiczne perspektywa ta okazuje się niezwykle cenna w odniesieniu do refleksji na temat edukacji. Autorzy tekstu, zaznaczają, że „immersja jako zjawisko konstruowane i kontrolowane świadomie stanowi bowiem wykorzystanie możliwości, które daje rozpoznanie emergentnej struktury rzeczywistości” (Polak, Polak, 2014: 139). Zgodnie z takim założeniem można przyjąć optymistyczną tezę, że jednostka nie jest biernym odbiorcą, ale aktywnym podmiotem poznającym rzeczywistość, konstruującym jej reprezentacje $\mathrm{w}$ porozumieniu $\mathrm{z}$ obrazami zapisanymi $\mathrm{w}$ pamięci „maszyny społecznej".

Rozstrzygnięciem proponującym podobną do powyższego narrację jest perspektywa koncentrująca się na obustronnej relacji indywidualnych jednostek oraz ponadjednostkowych struktur, jaką jest teoria strukturacji Anthony'ego. Giddensa (Giddens, 2003). Ten brytyjski socjolog, dokonując analizy różnorod-

\footnotetext{
${ }^{6}$ Zainteresowania tego badacza koncentrują się między innymi na koncepcji „maszyn społecznych”, którą przedstawia, poszerzając o kontekst współczesnego rozwoju środowisk wirtualnych i technologii immersji.
} 
nych koncepcji zajmujących się zagadnieniem funkcjonowania człowieka w perspektywie społecznej, doszedł do wniosku, że dyskursy uznające prymat struktury nad podmiotem dostarczają niewystarczających wyjaśnień na temat jednostkowego działania, z kolei badacze podmiotu nie przywiązują należytej wagi do znaczenia struktur społecznych. Dążył do stworzenia komplementarnej teorii, łączącej te biegunowe orientacje. Skonstruowana przez niego propozycja opiera się na złożeniu, że organizacje stanowią szansę dla rozwijania zbiorowej podmiotowości (Cybal-Michalska, 2013: 85). Jednostka posiadająca zdolność do odczytywania wartości nadanych symbolom społecznym może stać się decydentem podmiotem uczestniczącym w procesie przypisywania tych znaczeń. Ich rozpoznawanie, i co za tym idzie, powielanie, służy zatem reprodukcji, czyli wzmacnianiu istniejących układów. Procedura ta możliwa jest w wyniku funkcjonowania mechanizmu refleksyjności, który odzwierciedla samowiedzę oraz staje się środkiem „kontroli nieprzerwanego życia społecznego” (Giddens, 2003: 664). Tak nakreślona wzajemna zależność człowieka i społeczeństwa stanowi istotę teorii strukturacji.

Okazuje się zatem, że rozwój cywilizacji niesie ze sobą nie tylko wiele perspektyw i możliwości, ale również szkodliwych następstw przeobrażeń życia społeczno-kulturowego, takich jak destabilizacja, zagrożenie własnego istnienia, bezradność, odseparowanie, anonimowość czy zapośredniczenie relacji międzyludzkich (zob. Słomski, 2009). Dlatego też osnową myślenia o współczesnej edukacji jest udzielenie odpowiedzi na pytanie: Jak realizowana edukacja przygotowałaby podmiot do prorozwojowego funkcjonowania w świecie podlegającym permanentnej zmianie?

Próby dookreślenia roli tak rozumianej edukacji dokonuje Zbigniew Kwieciński, ujmując ją jako

ogół wpływów na jednostki i grupy ludzkie, sprzyjające takiemu ich rozwojowi, aby w najwyższym stopniu stały się one świadomymi i twórczymi członkami wspólnoty społecznej, kulturowej i narodowej oraz były zdolne do aktywnej samorealizacji własnej tożsamości i rozwijania własnego Ja poprzez podejmowanie zadań ponadosobistych, poprzez utrzymywanie ciągłości siebie w toku spełniania zadań dalekich. (Kwieciński, 1991: 89)

Autor tej definicji bardzo silnie akcentuje podmiotowy wymiar edukacji, zgodnie z którym ma ona służyć stworzeniu własnej koncepcji siebie, udzieleniu odpowiedzi na pytania: „kim jestem?” oraz „jaką pełnię rolę w systemie społecznym?". Ponadto, jednostka zobowiązana jest do rozwinięcia umiejętności planowania, a więc określania przyszłych celów. Na inny jej aspekt zwraca uwagę Teresa Wilk, która postuluje, by współczesna edukacja 
stała się przedstawicielem, a zarazem reprezentantem tej właśnie cywilizacji, w ramach której następuje przystosowanie do zaspokojenia i równocześnie rozbudzenia humanistycznych i intelektualnych potrzeb ludzkich. (Wilk, 2003: 17)

Podobną perspektywę przyjmuje Stanisław Palka, prognozując, że

edukacja jutra określana z punktu widzenia dzisiejszej rzeczywistości pedagogicznej będzie mieć z jednej strony głęboki wymiar humanistyczny, będzie skoncentrowana i na indywidualnościach uczniowskich, i na zespołach dzieci i młodzieży, z drugiej zaś strony ta edukacja będzie mieć wymiar działalności kształcącej, wychowującej, samokształcącej o wysokiej efektywności. (Palka, 1999: 57)

Z kolei Jerzy Kujawski formułuje główny cel edukacji koncentrujący się na „wszechstronnym i harmonijnym rozwoju osobowości ucznia w sferze instrumentalnej, kierunkowej i duchowej” (Kujawski, 2014: 43). Wszystkie przytoczone propozycje pozostają zgodne $\mathrm{z}$ myślą neoliberalnego projektu edukacji, osadzonego w nurcie humanistycznym, propagującego indywidualizm, podmiotową wolność i stającego w obronie naturalnych praw człowieka i jego autonomicznych wyborów (Walicki, Kraków 2013: 329) 7 .

Kreowanie edukacji w oparciu o teorię projektu stanowi interesujące poznawczo rozstrzygnięcie. Przede wszystkim skłania do namysłu nad jej autotelicznością oraz niezależnością od systemów społecznych (zob. Lewin, 1935) ${ }^{8}$ oraz rodzi pytania o to, czy nie jest ona ograniczona pewnego rodzaju ramami konceptualnymi, które służą realizacji zamierzeń ich twórców, a nie dobru podmiotu, a także o to, czy rozwój edukacji w duchu nurtu liberalnego jest dla niej jedynym słusznym rozwiązaniem i nie przyczynia się do zawężania obszaru refleksji o niej. Współczesne kształcenie koncentrujące się na propagowaniu idei ponoszenia odpowiedzialności za swoje czyny oraz przekonaniu podlegających mu jednostek o własnym sprawstwie i zdolności do zarządzania własnym życiem - zdecydowanie znajduje swoje odzwierciedlenie $w$ neoliberalnej wizji człowieka. Eugenia Potulicka, podejmując próbę wnikliwej analizy uwikłania edukacji w zależności

\footnotetext{
${ }^{7}$ Rozstrzygnięcie to pozytywnie zapatruje się również na kwestię wolnego rynku, który stanowi płaszczyznę emancypacji i samorealizacji jednostek. Autor wspomnianej pozycji do takiego ujęcia odnosi się raczej krytycznie, dostrzegając w wolnym rynku ograniczenie wolności, uwikłanie podmiotu w różnego rodzaju powiązania, które blokują jego szansę na rozwój.

${ }^{8}$ W kontekście powyższych rozważań warto wspomnieć o koncepcji pola K. Lewina, zgodnie z którą istnieje zależność pomiędzy polem psychicznym jednostki a jej środowiskiem zewnętrznym. Przestrzeń życiowa podmiotu zostaje podzielona na obszary, które nabierają znaczenia w kontekście potrzeb jednostki. Mogą pozostawać ze sobą w relacji pozytywnej lub negatywnej, dlatego znaczące jest utrzymanie pomiędzy nimi homeostazy.
} 
tego nurtu, skłania się ku stwierdzeniu, że powiązania te są tak intensywne, że nie sposób ich rozdzielać (zob. Potulicka, Rutkowiak, 2010) ${ }^{9}$.

Edukacja rozumiana jako projekt kontynuuje myśl wcześniej wspomnianej teorii „maszyny społecznej”, która stanowi czynnik napędzający (dający energię) jego realizację. Opiera się więc na triadzie tworzących ją elementów strukturalnych, takich jak: „projekt”, „przejmowanie energii” i „potwierdzenie/sukces” (Polak, Polak, 2014: 144), pomiędzy którymi istnieje stopniowa zależność. W tym kontekście „projekt” stanowi pojęcie bardzo szerokie, odnoszące się do pewnego planu odnajdującego odzwierciedlenie w realiach społecznych i co za tym idzie egzystencji podmiotu. Koncepcja ta wydaje się wygodna dla edukacji, ponieważ przynosi „poczucie bezpieczeństwa, przejęcia odpowiedzialności, zwolnienia z wymagań ustanawiania kryteriów tejże odpowiedzialności” (Polak, Polak, 2014: 145). Za zdecydowany walor niniejszego ujęcia można uznać jego wymiar pragmatyczny, wyrażający się w możliwości spełnienia potrzeb kreującego ją społeczeństwa. W sytuacji, gdy istniejący projekt przestaje być wystarczający - tworzy się nowy o innej jakości.

Podjęta narracja dotycząca przemian globalizacyjnych mających miejsce w ostatnim czasie zachęca do refleksji nad filarami edukacji. Przyjmując idealistyczne założenie, że jej główny cel powinien koncentrować się na optymalnym przekazywaniu wiedzy i kształtowaniu zdolności jednostek niezbędnych do egzystencji we współczesnej rzeczywistości, za Jacques'em Delorsem można stwierdzić, że podstawowe filary edukacji stanowią: uczyć się „aby wiedzieć, uczyć się” aby działać, uczyć się „aby żyć wspólnie, uczyć się” aby być (Delors, 1998: 85-98). Wnikliwa analiza przytoczonych idei pozwala na odnalezienie w nich wartości ponadczasowych. Jednak opierając się na założeniu, że edukacja stanowi proces podlegający przemianom zależnym od tendencji rozwojowych społeczeństw (Wilk, 2002: 12), należy przypuszczać, że jej dążenia będą dookreślane przez aktualne konfiguracje tychże zmian (w tym również politycznych). Taki postulat znajduje odzwierciedlenie w klasycznej definicji edukacji Wincentego Okonia, utożsamiającej ją z „ogółem procesów i oddziaływań, których celem jest zmienianie ludzi, przede wszystkim dzieci i młodzieży - stosowanie do panujących

\footnotetext{
${ }^{9}$ Druga z autorek tej pozycji, J. Rutkowiak, akcentuje także, że wzajemne konotacje edukacji i ekonomii są tak wyraźne, że nie da się ich zatrzymać. Ekonomia neoliberalna, która w tej relacji postrzegana jest jako jedynie słuszna, podporządkowuje sobie edukację, czego wynikiem okazuje się człowiek bezmyślny - pragmatyczny z punktu widzenia rynku. Prognozuje jednak kreowanie się nowej wizji ekonomii kulturowej oraz edukacji poneoliberalnej, pomiędzy którymi dochodzi do „refleksyjnej wymiany”, a funkcjonujący w niej podmiot ma dostęp do różnorodnej wiedzy i „tworzy perspektywy poszerzania kategorii świata, jako znaczącej dla relacji człowieka z rzeczywistością” (zob. Potulicka, Rutkowiak, 2010: 354-355)
} 
w danym społeczeństwie ideałów i celów wychowawczych" (Okoń, 2007: 93). Propozycja Delorsa nadal stanowi jedną z najczęściej przytaczanych w literaturze, dlatego też nie można zaprzeczać jej aktualności, jednakże specyfika obecnych czasów sprawia, że ich priorytetowe znaczenie ulega zatracaniu na rzecz postulatów sukcesu, samorealizacji i pragmatyzmu, których konsekwencją jest relatywizm moralny (Dolata, 2002: 57-66). W sytuacji, w której moralność ulega procesowi prywatyzacji (zob. Melosik, 1999), budowanie społeczeństwa samorealizujących i samodefiniujących się podmiotów staje się zadaniem beznadziejnym, ponieważ skutkuje sumowaniem się postaw egoistycznych (Dolata, 2002: 60), efektem czego jest propagowanie zasady indywidualnej odpowiedzialności za własne sprawstwo.

Problemy współczesnej edukacji koncentrują się zatem na formowaniu się różnego rodzaju nierówności społecznych, często będących wynikiem oddziaływania także jej mechanizmów. Zdaniem A. Gromkowskiej-Melosik w dyskusjach na temat stratyfikacyjnej roli edukacji prezentują się dwa dyskursy. Jeden z nich opiera się na tezie, że dyplom akademicki może stanowić „przepustkę do lepszego życia", dlatego też powinno się upowszechnić dostęp do szkolnictwa wyższego, drugi zaś, wyrastający z narracji habitusu i „reprodukcji społecznej” (zob. Bourdieu, 2006), utrzymuje, że szansę na odniesienie sukcesu mają jednostki pochodzące $\mathrm{z}$ dobrze usytuowanych rodzin (Gromkowska-Melosik, 2003: 32-33). Warto zaznaczyć, że zagadnienie różnicowania odnosi się także do poziomów jakości kształcenia realizowanego przez placówki edukacyjne ${ }^{10}$. W czasach, w których „w edukację i więzi społeczne inwestuje się tak, jak w każde inne przedsięwzięcie gospodarcze - po to, aby zarobić" (Szkudlarek 2005: 14), na ryn$\mathrm{ku}$ edukacyjnym obowiązują zasady nieograniczonej konkurencji. Instytucje oświatowe, kierując się chęcią odniesienia ekonomicznego sukcesu (wygrywając rywalizacyjną walkę w sprzedaży swoich usług), zamieniają naukę $\mathrm{w}$ „towar”. Społeczne oczekiwania wobec edukacji, coraz częściej sprowadzają się zatem do uzyskania jednostek produktywnych i skutecznych w sensie ekonomiczno-gospodarczym, niż zorientowanych na samorealizację i wszechstronny rozwój osobowości.

W kontekście współczesnych przemian nie sposób rozpatrywać roli edukacji bez uwzględnienia znaczenia rynku pracy. Zasadność tego twierdzenia potwierdza myśl W. Hornsteina, który utrzymuje, że jednym z jej zadań jest „przygoto-

\footnotetext{
${ }^{10}$ Przez efektywność kształcenia rozumie się tutaj za K. Denkiem „zespół pozytywnych cech procesu dydaktyczno0wychowawczego, działań sensownych i optymalnych, a jednocześnie społecznie i ekonomicznie uzasadnionych, przynoszących najlepsze rezultaty w postaci wyników w nauce (obejmujących: wiedzę, umiejętności, nawyki, zainteresowania i zdolności poznawcze, motywy, przekonanie i przyzwyczajenie do ustawicznego kształcenia)" (Denek, 1992: 42).
} 
wanie nowego pokolenia do wymagań kwalifikacyjnych systemu zatrudnienia, który stanowi - przynajmniej zgodnie z założeniem - pozytywną ocenę zdobytych w młodości kwalifikacji oraz koniecznych w zawodowej praktyce właściwości moralnych i społecznych" (Hornstein, 2005: 16). Aktywność zawodowa staje się rodzajem działalności, pochłaniającym coraz większy wycinek egzystencji podmiotu, zatem istotne jest wykształcenie zdolności do podjęcia przyszłej roli zawodowej. „Uzależnienie jakości wiedzy od wymagań globalnego rynku, który wiąże się przede wszystkim z efektywnością i wykorzystywaniem informacji w działaniu do celów produkcji, innowacji i zarządzania” (Cybal-Michalska, 2010: 23) sprowadza do postrzegania edukacji przede wszystkim przez pryzmat użyteczności.

Rozstrzyganie zależności pomiędzy rynkiem a edukacją stanowi wątek niezbędny w obliczu prowadzonej dyskusji. Traktowanie tych obu płaszczyzn jako obszarów niezależnych grozi samounicestwieniem społeczeństwa opartego na wiedzy. Uwarunkowania tych koligacji warto rozpatrywać z perspektywy popularnego obecnie zagadnienia public relations (Wójcik, 1997), w myśl którego są one ze sobą połączone na zasadzie komplementarności. W konsekwencji edukacja zobligowana jest do dostarczania społeczeństwu odpowiednio ukształtowanych jednostek zgodnie $\mathrm{z}$ jego potrzebami, natomiast rynek powołany jest do racjonalnego ich wykorzystywania. Relacja ta ma charakter permanentnej homeostazy, w której wraz ze zmianą oczekiwań rynku, edukacja doskonali kompetencje obecnych na nim podmiotów (idea całożyciowego uczenia się ${ }^{11}$ ). Układ ten byłby rozwiązaniem idealnym, jednak w sytuacji dynamicznych przemian potrzeba wzajemnej reakcji okazuje się tak szybka, że zawodzą nawet działania prognostyczne, w efekcie czego mamy do czynienia z sytuacją wzajemnego obwiniania się.

Konkludując powyższe rozważania, warto poddać namysłowi przesłanie zawarte w stwierdzeniu Z. Kwiecińskiego:

współczesność nieustannego kryzysu wymaga typu człowieka, który może sprostać trudnym okolicznościom i zadaniom. Człowieka pełnomocnego - o ukształtowanych kompetencjach do formułowania i rozwiązywania nowych, trudnych zadań, mądrego, odpowiedzialnego, współczującego i zdolnego do solidarnego współdziałania, umiejącego krytycznie wybierać i osądzać (...). (Kwieciński, 2000: 84-85)

Może ono stanowić cenną myśl dla edukacji. W świecie różnorodności, permanentnej zmiany i przenikania znaczeń korzystną propozycją staje się szeroko

\footnotetext{
${ }^{11}$ Patrz: Commission of the European Communities, White Paper on Sectors and Activities Excluded from the Working Time Directive, Brussels 1997.
} 
pojęta edukacja globalna, której celem jest nie tylko wyposażenie podmiotu w wiedzę i umiejętności, ale także wykształcenie w nim tendencji do nieustannego weryfikowania własnych zasobów i co za tym idzie - ciągłego doskonalenia. Czynnikiem warunkującym odniesienie sukcesu we współczesnej rzeczywistości jest przede wszystkim kreatywność, która sprzyja rozwojowi postawy przedsiębiorczej i elastycznej oraz proaktywność ukierunkowana na konsekwentne realizowanie przyjętej wizji siebie (Bańka, 2009: 10-23). Zdaniem Zbyszka Melosika priorytetowym zadaniem edukacji globalnej jest kształtowanie "globalnej świadomości”, zorientowanej na postrzeganie podmiotu jako obywatela świata (Melosik, 2001: 29-33) ${ }^{12}$. Postulat ten odnosi się nie tylko do dzieci i młodzieży, poddawanych przymusowym oddziaływaniom edukacji, ale także do dorosłych, którzy, chcąc przetrwać w starciu z „maszyną” współczesności, zobligowani są do nieustannego rozwoju. W refleksji tej nie należy pomijać roli osób przygotowujących się do zawodu nauczyciela lub pełniących go, którzy powołani do przygotowywania młodych ludzi do aktywnego życia w zglobalizowanej rzeczywistości, powinni dbać o własny progres oraz korzystać z odpowiednio zorganizowanego systemu kształcenia.

Tak rozumiana edukacja stanowi pewien rodzaj relacji (nieustannego dialogu), którego aktywnymi podmiotami są wszystkie organy wspierające jej przebieg, zarówno organizatorzy tego procesu określający zakres jej treści, kanony programowe oraz metody nauczania, jak i również rodzina, środowisko lokalne oraz adresaci tej propozycji, pełniący także rolę jej odbiorców. Bez względu na stosunek do zglobalizowanej rzeczywistości (negatywny - koncentrowany na wymogach konformizmu, zredukowany do praw wolnego rynku, lub pozytywny - bazujący na wierze $\mathrm{w}$ nieograniczony potencjał poznawczy jednostki oraz drzemiący w niej czynnik sprawczy), jesteśmy skłonni zgodzić się ze stwierdzeniem, że przyszłość świata, a co za tym idzie - ludzkości, zależy od kształtu oraz jakości edukacji. Dlatego też, powinna być ona zorientowana na stwarzanie oraz wykorzystywanie szans i możliwości istotnych dla prawidłowego rozwoju człowieka (Kukla, 2010: 29) ${ }^{13}$.

\footnotetext{
${ }^{12}$ Kategoria „globalnej świadomości” odnosi się także do kwestii odpowiedzialności. Jednostka zobligowana jest nie tylko do korzystania z możliwości oferowanych przez współczesną rzeczywistość, ale także ponosi współodpowiedzialność za dokonujące się w niej przemiany. Ponadto, pozostaje w przekonaniu o istnieniu pewnych podobieństw pomiędzy ludźmi na całym świecie, jakim są potrzeby biologiczne i psychologiczne czy dylematy egzystencjalne.

${ }^{13}$ Do wspomnianych szans z pewnością należy zaliczyć: nieograniczony i szybki dostęp do informacji, możliwość nawiązywania kontaktów w sposób zapośredniczony za pomocą szeroko pojętych mediów, w tym Internetu (co zapewnia kontakt z kulturą ogólnoświatową), oraz mobilność uczniów i nauczycieli.
} 


\section{Literatura}

Bańka A. (2009). Proaktywność - intencjonalne konstruowanie przyszłości i uprzedzające osiaganie celów personalnych poprzez doświadczanie codzienności. [W:] H. Wrona-Polańska, E. Czerniawska, L. Wrona (red.). Szkice o ludzkim poznawaniu i odczuwaniu. Kraków.

Bauman Z. (1993). Ponowoczesne wzory osobowe. „Studia Socjologiczne” nr 2 (19).

Bauman Z. (2000a). Globalizacja. Warszawa.

Bauman Z. (2000b). Ponowoczesność jako źródło cierpień. Warszawa.

Bauman Z. (2007). Płynne życie. Kraków.

Bokszański Z. (1988). Tożsamość jednostki. „Kultura i Społeczeństwo” nr 2.

Bokszański Z. (2009) O indywidualistach w społeczeństwie wspótczesnym. „Studia Socjologiczne” nr 1⁄2. Bourdieu J. (2006). Reprodukcja. Elementy teorii systemu nauczania. Warszawa.

Burszta W.J. (1998). Antropologia kultury. Poznań.

Commission of the European Communities. (1997). White Paper on Sectors and Activities Excluded from the Working Time Directive. Brussels.

Cybal-Michalska A. (2006). Tożsamość młodzieży w perspektywie globalnego świata. Studium socjopedagogiczne. Poznań.

Cybal-Michalska A. (2010). Prorozwojowość jako kategoria edukacyjna społeczeństwa zorientowanego na wiedzę. „Studia Edukacyjne” nr 12.

Cybal-Michalska A. (2013). Młodzież akademicka a kariera zawodowa. Kraków.

Ćwikliński A. (2005). Zmiany w polskiej edukacji w okresie globalizacji, integracji $i$ transformacji systemowej. Poznań.

Delors J. (1998). Edukacja jest w niej ukryty skarb. Warszawa.

Denek K. (1992). Nowe paradygmaty pomiaru efektywności w szkolnictwie zawodowym. „Pedagogika Pracy" nr 20/2.

Dolata M. (2002). Konsekwencje edukacyjne relatywizmu - globalizm versus uniwersalizm. [W:] A. Radziewicz-Winnicki (red.). Edukacja a życie codzienne. T. 1. Katowice.

Dorna N. (2001). Indywidualizm-kolektywizm jako źródło międzykulturowych różnic w zakresie zachowań komunikacyjnych. [W:] Z. Blok (red.). Społeczne problemy globalizacji. Poznań.

Foucault M. (1993). Nadzorować i karać. Narodziny więzienia. Warszawa.

Gerlach R. (2006). Edukacja zawodowa w aspekcie rynku pracy. [W:] Kształcenie Zawodowe: Pedagogika i Psychologia: rocznik polsko-ukraiński, nr VIII.

Giddens A. (1997). Socjologia. Zwięzłe, lecz krytyczne wprowadzenie. Poznań.

Giddens A. (2003). Stanowienie społeczeństwa. Zarys teorii strukturacji. Poznań.

Giddens A. (2008). Konsekwencje nowoczesności. Kraków.

Golka M. (1999). Cywilizacja. Europa. Globalizacja. Poznań.

Golka M. (2001). Kultura w przestrzeni globalnej. [W:] Z. Blok (red.). Społeczne problemy globalizacji. Poznań.

Gromkowska-Melosik A. (2003). Stratyfikacja, ruchliwość społeczna, edukacja - kilka uwag teoretycznych. [W:] T. Gmerek (red.). Edukacja i stratyfikacja społeczna. Poznań.

Hornstein W. (2005). Wychowanie i edukacja w epoce globalizacji. „Pedagogika Społeczna” nr 1.

Kujawski J. (2014). Szkoła XXI wieku i jej atrybuty. Poznań.

Kukla D. (2010). Preorientacja i orientacja zawodowa w edukacji. Warszawa. 
Kwieciński Z. (1991). Edukacja jako wartość odzyskiwana wspólnie. „Edukacja” nr 1.

Kwieciński Z. (2000). Tropy, ślady, próby. Poznań-Olsztyn.

Lewin K. (1935). A Dynamic Theory of Personality; Selected Papers. New York.

Liberska B. (2002). Globalizacja - sity sprawcze i mechanizmy. [W:] B. Liberska (red.). Globalizacja. Mechanizmy i wyzwania. Warszawa.

Mathews G. (2005). Supermarket kultury. Warszawa.

Mayor F. (2001). Przyszłość świata. Warszawa.

Melosik Z. (1995). Postmodernistyczne kontrowersje wokót edukacji. Toruń-Poznań.

Melosik Z. (2001). Młodzież, styl życia: paradoksy pop-tożsamości. [W:] Z. Melosik (red.). Młodzież, styl życia i zdrowie. Konteksty i kontrowersje. Poznań.

Melosik Z., Szkudlarek T. (2010). Kultura, tożsamość i edukacja. Migotanie znaczeń. Kraków.

Mikułowski-Pomorski J. (2006). Fragmentaryzacja jako proces ponowoczesny. Rekompozycja poprzez fragmentaryzację. „Transformacje”, nr 1/4, s. 47-50.

Okoń W. (2007). Nowy słownik pedagogiczny. Warszawa.

Palka S. (1999). Nauki pedagogiczne a edukacja jutra. [W:] K. Denek, T.M. Zimny (red.). Edukacja jutra. VI Tatrzańskie Seminarium Naukowe. Częstochowa.

Polak T., Polak B.A. (2014). O potrzebie i możliwościach wypracowania zintegrowanej teorii „maszyn społecznych". [W:] W. Ambrozik (red.). Edukacja. Uniwersytet. Oświata dorostych. Studia z pedagogiki ofiarowane Profesorowi Kazimierzowi Przyszczypkowskiemu. Poznań.

Potulicka E., Rutkowiak J. (2010). Neoliberalne uwikłania edukacji. Kraków.

Pucek Z. (2004). Tożsamość w przestrzeni wielokulturowej. „Państwo i Społeczeństwo” r. IV, nr 3.

Ritzer G. (1997). Macdonaldyzacja społeczeństwa, Warszawa.

Słomski W. (2009). Człowiek pośród dylematów i wyzwań etycznych współczesności. Warszawa.

Szkudlarek T. (2005). „Koniec pracy” czy koniec zatrudnienia? Edukacja wobec presji światowego rynku. [W:] A. Kargulowa, S. Kwiatkowski, T. Szkudlarek (red.). Rynek i kultura neoliberalna a edukacja. Kraków.

Szmyd J. (2006). Tożsamość a globalizacja. Kraków.

Szul R. (1997). Epokowe wyzwania gospodarcze a społeczny wymiar gospodarowania. [W:] A. Doroczyńska (red.), Jednolitość i różnorodność w polityce rozwoju. Warszawa.

Tobera P. (2000). Niepokojąca nowoczesność. „Kultura i Społeczeństwo” nr 3.

Walicki A. (2013). Od projektu komunistycznego do neoliberalnej utopii. Kraków.

Wilk T. (2002). Równość i sprawiedliwość społeczna wobec edukacji jutra. [W:] A. Radziewicz-Winnicki (red.). Edukacja a życie codzienne. T. 2. Katowice.

Wilk T. (2003). Edukacja, wartości i style reprezentowane przez współczesna młodzież w Polsce w odmiennych regionach gospodarczych. Kraków.

Wójcik K. (1997). Public relations od A do Z. t. I i II. Warszawa.

\section{Education in the World of Globalization}

\section{Summary}

The contemporary human condition is not free from the influence of its context based on the tendency of global changes. Living in the world of 'flickering meanings' and 'liquid life' is at the 
bottom of axionormative diversity that spreads itself in almost every sphere of the subject's life. For one thing, we are facing situation of cooperation and mutual support, but then again, we can observe areas of social inequality and extreme poverty. All this is a proof of the globalization's heterogeneity, with emphasis to be placed on its ambiguous character. Processes of cultural unification together with creation of common markets and network of mutual connections cause the formation of a particular relation of supranational range. However, fragmentation and creeping relativism of values lead to the breakdown of the solid structure of the subject's identity. The conglomerate of all the above-mentioned circumstances has also its influence on the education which aims to prepare the individual for functioning within encountered reality.

Education, which only a few dozen years ago was the determinant of the professional future, nowadays, is merely one of the constituents of the full résumé. Consequently, the question 'How to put education into practice, so it can prepare the subject for prodevelopmental functioning in the permanently changing world?' appears within the context of considerations about this issue. An attempt of answering that question can be made in accordance with the narration of "social machines", which gives to the individual an apparent impression of freedom in the process of cognition of the social world. Another solution would be to focus on their comprehensive development and strengthen their individuality.

The majority of the contemporary solutions concerning the education lie within the neoliberal scope. The watchwords promoted by this policy such as: freedom, possibility of every individual to achieve success, or competition, reflect the laws of the contemporary free market, resulting in the interpenetration of those grounds. Educational establishments, directing their step towards the economic success (through the medium of winning in the competitive battle of providing chargeable services) turn science into a 'commodity'. Society's expectations towards education more and more frequently consist in gaining productive and efficient human resources in the economic and commercial area, without paying attention to the self-fulfillment or comprehensive personality development.

In the world of multiplicity, permanent changes, and interpenetrating meanings, broadly defined global education seems to be an advantageous proposal in order not only to provide knowledge and abilities to the subject but also to verify continuously their learning, and hence constant improvement. Creativity, which encourages development of enterprising and flexible attitude as well as proactivity, is the main factor determining the success in the contemporary reality.

Regardless of our stand towards globalized reality (negative: focused on the requirements of conformity, reduced to the law of free market economics; or positive: based on the belief in unlimited cognitive potential of the subject and in its causative factor) we are willing to agree that the world's future, and hence the mankind's destiny, depends on the shape and quality of education. Therefore, it should be oriented towards creating opportunities and chances together with making the most of them for proper human development. 